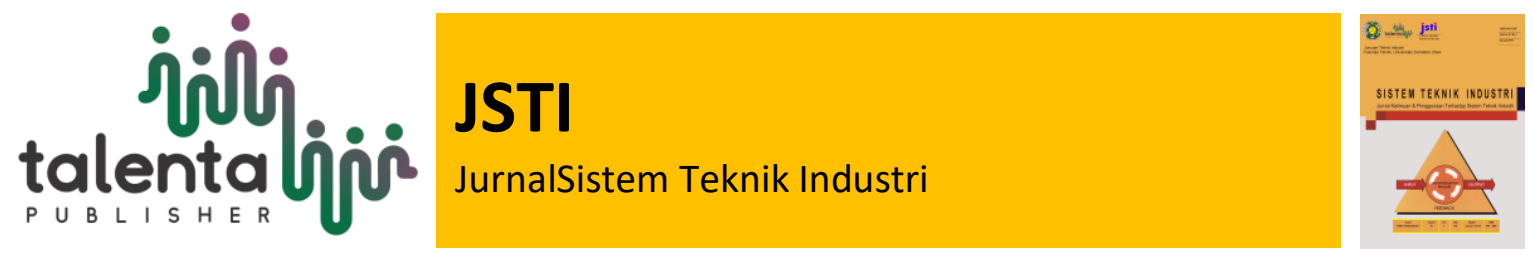

\title{
Redesain Alat Pemotong Singkong Menggunakan Metode Rasional Guna Meningkatkan Produktivitas
}

\author{
Miftakhul Ulum ${ }^{1}$, Ratih Setyaningrum ${ }^{2}$, Tita Talitha ${ }^{3}$ \\ 1,2,3 Program Studi Teknik Industri, Fakultas Teknik Universitas Dian Nuswantoro Semarang
}

\begin{abstract}
Cassava chips are a daily staple food for the community, cassava chips have a distinctive form that has never been changed since the first time they were made, namely a circular flat with a crispy texture. Cassava chips are food products made from cassava which have been known for a long time in Indonesia, cassava chips are also widely favored by the Indonesian people because they have a delicious, nutritious taste and the price is also affordable. Based on observations at SMEs know in the village of Manggar, Sluke District, Rembang Regency. It is known that the process of making cassava chips through various stages, ranging from the selection of cassava, cassava stripping and cassava cutting to pressing. In Mubarok UKM the cutting process is only done in 3 hours a day and in one month it is only done in 15 days. In Mubarok UKM, the cutting process still uses a simple tool, namely a knife, and a thread cutter by hand as the motor. With existing tools in UKM there are process constraints that are manual and require a long time, the resulting output is a little with a long time and the quality of pieces that are not uniform and the tools used are less ergonomic, the size of the tool, the tool still causes workers to be diseased, causing a decrease productivity. In this case I designed a tool for cassava cutters to improve the effectiveness and productivity of the MSME. The method used in the design of the tool is methodological. The rational method is one of the product design methods that uses a systematic approach at each stage to produce potential solutions.
\end{abstract}

Keyword: Cutting, Productivity, Cassava, Rational Method

\begin{abstract}
Abstrak: Keripik singkong merupakan salah satu makanan khas Indonesia yang banyak digemari oleh masyarakat Indonesia karena memiliki cita rasa yang nikmat, bergizi tinggi dan harganya juga terjangkau. Berdasarkan hasil pengamatan di UKM kripik singkong di desa Manggar, Kecamatan Sluke, Kabupaten Rembang. Diketahui proses pembuatan kripik singkong melalui berbagai tahapan, mulai dari pemilihan singkong, pengupasan singkong dan pemotongan singkong sampai dengan pengepresan. Di UKM Mubarok proses pemotongan hanya dilakukan dalam 3 jam saja dalam sehari dan dalam satu bulan hanya dikerjakan dalam 15 hari. Di UKM Mubarok proses pemotongan masih menggunakan alat sederhana yaitu pisau, dan pemotong ulir dengan menggunakan tangan sebagai motornya. Dengan alat yang ada pada UKM terdapat kendala prosesnya yang manual dan membutuhkan waktu yang lama, output yang dihasilkan sedikit dengan waktu yang cukup lama dan kualitas potongan yang tidak seragam dan alat yang digunakan kurang ergonomis, ukuran alat, alat masih menimbulkan kelelahan pekerja sehingga menimbulkan menurunnya produktivitas. Berdasakan permasalahan diatas, maka tujuan penelitian yaitu merancang alat untuk pemotong singkong guna meningkatkan efektifitas dan prduktivitas UMKM tersebut. Metode yang digunakan dalam perancangan alat tersebut adalah metode rasional. Metode rasional merupakan salah satu metode perancangan produk yang menggunakan pendekatan sistematis dalam tiap tahapan untuk menghasilkan solusi yang potensial. Hasil penelitian dengan menggunakan alat rancangan yang baru yaitu Dengan menggunakan alat baru memiliki tingkat kepresisian tertinggi 95\% dengan tingkat ketebalan produk $0.3 \mathrm{~cm}$ dan peningkatan jumlah produk meningkatkan efisiensi sebesar $83 \%$. Hasil tersebut menunjukkan bahwa produktivitas mampu meningkat sebesar $83 \%$.
\end{abstract}

Kata kunci : pemotong, produktivitas, singkong, Metode Rasional

Received 11 Desember 2019| Revised 20 Januari 2020 | Accepted 26 Januari 2020

*Corresponding author at: Universitas Dian Nuswantoro Semarang,Indonesia

E-mail address: Ratih Setyaningrum <ratihha@gmail.com>

Copyright @ 2020 Published by Talenta Publisher, ISSN: 1411-5247 e-ISSN: 2527-9408

Journal Homepage: http://talenta.usu.ac.id/jsti 


\section{Pendahuluan}

Perkembangan teknologi industri yang secara pesat tidak hanya menawarkan pilihan produk yang sangat beragam tetapi juga diikuti dengan berbagai pilihan harga yang sangat terjangkau. Hal ini sangat memberikan peluang kepada masyarakat untuk mampu bersaing dalam perkembangan yang ada. Usaha Mikro Kecil Menengah (UMKM) merupakan salah satu pendorong kemajuan ekonomi dan teknologi Indonesia karena perannya dalam memberikan peluang kerja bagi masyarakat dan peluang inovasi bagi masyarakat. Hal ini terbukti dengan perkembangan jumlah UMKM yang terus meningkat tiap tahunnya. Bidang usaha yang paling banyak atau dominan pada UKM adalah bidang usaha industri pembuatan bahan makanan atau pakan karena kebutuhan masyarakat dengan kuliner semakin berkembang.

Pada penelitian sebelumnya, beberapa teknologi diimplementasikan pada alat potong agar mengingkatkan kinerja UKM diantaranya UKM singkong kentang [1], Perancangan produk memiliki berbagai tahapan dan disesuaikan dengan target konsumen yang dituju [2].Alat pemotong singkong yang sebelumnya perlu dikembangkan lagi agar meningkatakan produktivitas [3].

Salah satu makanan yang sering diminati oleh semua kalangan yaitu kripik singkong. Berdasarkan hasil pengamatan di UKM Mubarok pembuatan kripik singkong diketahui proses pembuatan kripik singkong melalui beberapa tahapan, pemilihan singkong, pengupasan singkong, pencucian singkong, pemotongan singkong, pemberian rasa dan pengemasan. Dalam sehari UKM Mubarok menghabiskan sekitar $30 \mathrm{~kg}$ singkong. Pada tahap pemotongan merupakan tahapan yang menjadi kendala pada UKM Mubarok. Dimana pada proses tersebut memerlukan waktu sekitar 90-100 menit. Proses pemotongan singkong hanya dilakukan dalam 3 jam saja dalam sehari dan dalam satu bulan hanya dikerjakan dalam 15 hari.

Proses pemotongan singkong di UKM ini masih menggunakan alat sederhana yaitu pisau, dan pemotong ulir dengan menggunakan tangan sebagai motornya. Dengan alat yang ada pada UKM terdapat kendala prosesnya yang manual dan membutuhkan waktu yang lama, output yang dihasilkan sedikit dengan waktu yang cukup lama dan kualitas potongan yang tidak seragam. Alat yang digunakan kurang ergonomis, ukuran alat, alat masih menimbulkan kelelahan pekerja sehingga menimbulkan menurunnya produktivitas. Ketentuan ketebalan 0.3 $\mathrm{cm}$ terkadang bisa melebihi bahkan juga kurang dari ukuran yang ditentukan. Alat yang ada di pasaran yang sudah beredar saat ini yaitu masih dengan cara manual mulai dari pisau, kotak pemotong, dan alat ulir manual. Alat yang digunakan di UKM juga termasuk alat yang ada di pasaran saat ini, masih menggunakan manual, proses membutuhkan waktu yang lama, output 
yang dihasilkan sedikit dengan waktu yang cukup lama dan kualitas potongan yang tidak seragam. Oleh sebab itu produktivitas saat ini masih belum optimal. Alat yang digunakan kurang nyaman, alat ketika digunakan bergerak memicu terjadinya kelelahan dan rentan cidera pada pengguna. Dimensi alat kurang memperhatikan unsur ergonomi. Mulai dari dimensi vertikal dan horisontal alat. Berdasarkan permasalahan proses pemotongan saat ini, dalam penelitian ini akan merancang sebuah alat pemotong singkong yang efektif dan efisien guna meningkatkan produktivitas kripik singkong pada UKM Mubarok dengan metode Rasional.

Urgensi penelitian ini ditujukan untuk meningkatkan produktivitas, efisiensi dan efektif ditinjau dari jumlah output, waktu proses dan kualitas produk serta meminimalkan cidera. Oleh sebab itu, rancangan dan implementasi alat pemotong sangat diperlukan untuk meningkatan produktivitas, efisiensi dan efektivitas.

\section{Metode Penelitian}

Penelitian dilakukan dengan menggunakan metode rasional. Metode rasional terdiri dari 7 tahapan antara lain clarifying objective, establishing function, setting requirements, determining characteristics, generating alternatives, evaluating alternatives dan product improvement [4]. Tahap metode clarifying objektif, metode ini menggunakan format yang jelas dan berguna untuk pernyataan suatu tujuan. Objective Tree menunjukkan tujuan yang sedang dalam pertimbangan. Tahap establishing function, metode ini menawarkan cara-cara untuk mempertimbangkan fungsi-fungsi dasar dan tujuan tingkat masalahnya. Fungsi dasar tersebut adalah fungsi dimana alat-alat, produk dan sistem yang akan dirancang harus meyakinkan, atau tidak peduli dengan komponen fisik yang digunakan. Tahap setting requirements, metode yang dipakai adalah The Performance Spesification Methods. Metode ini bertujuan membantu menemukan masalah perancang. Tahap determining characteristics, untuk dapat menetapkan target yang akan dicapai oleh karakteristik teknik produk sehingga dapat mewujudkan kebutuhan konsumen, salah satu metode yang digunakan yaitu metode Ergonomic Function Deployment (EFD).Tahap generating alternatives, Tujuan dari pembangkitan alternatif adalah untuk membangkitkan solusi-solusi rancangan alternative atau memperluas ruang pencarian terhadap solusisolusi baru yang potensial. Tahap evaluating alternatives, Tujuan dari metode ini untuk mengambil suatu keputusan alternatif dalam pengembangan alternatif- alternative yang sudah ada.Tahap product improvement, Pada tahap ini dilakukan penyempurnaan dari produk hasil rancangan. Penyempurnaan produk dapat dilakukan dengan melihat segi kenyamanan maupun keindahan (estetika) produk [5] .

Tahapan penelitian yang dilakukan disajikan pada Gambar 1 sebagai berikut: 


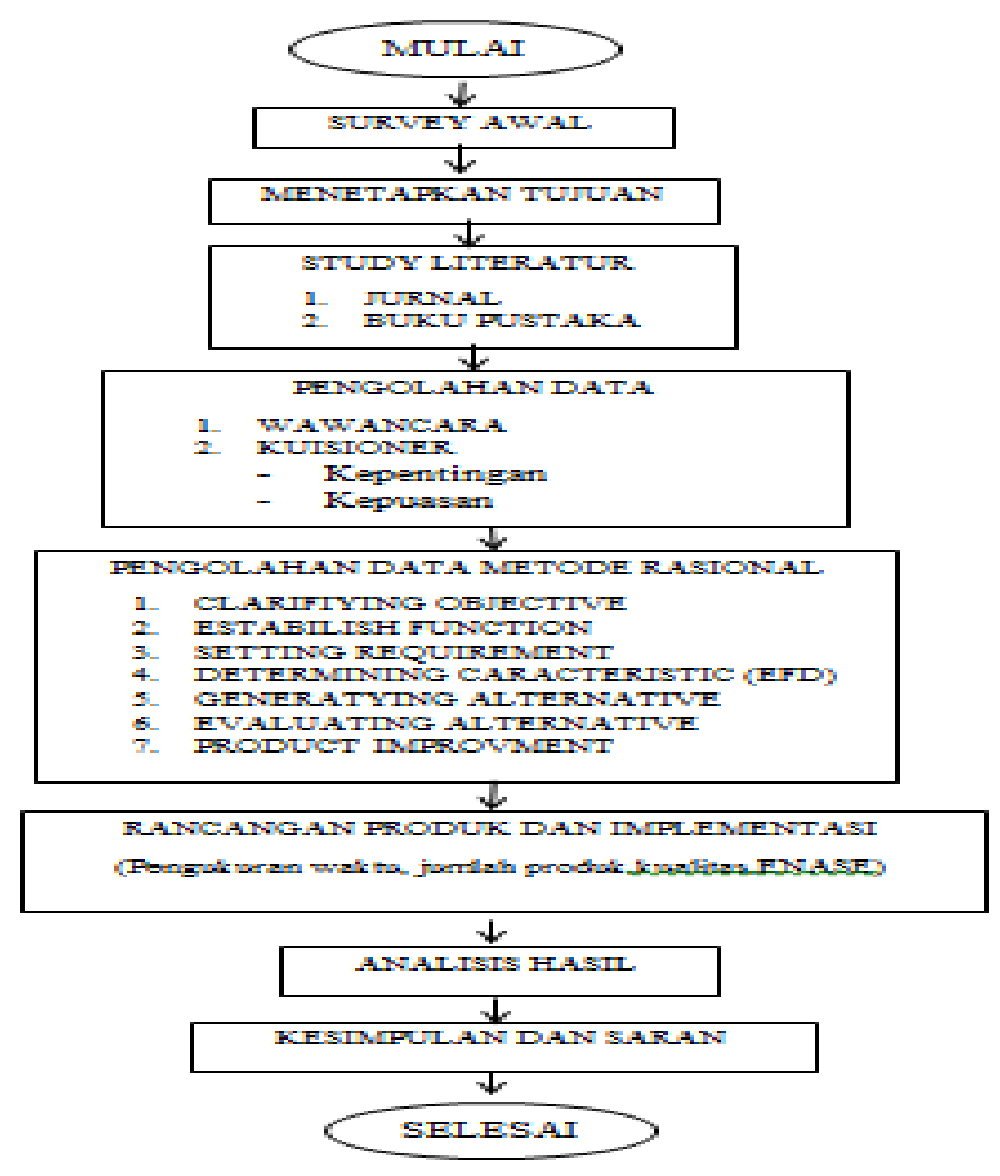

Gambar 1. Alur penelitian

\section{Hasil dan Pembahasan}

\subsection{Clarifying Objectives}

Pada tahapan awal dari metode rasional Clarifying Objectives menjelaskan bagaimana tujuan perancangan alat pemotong secara terstruktur dengan menggunakan metode Objective Tree (pohon tujuan) sehingga dapat menunjukkan hubungan dari berbagai sub tujuan bagaimana mencapai tujuan tersebut. Berikut merupakan Objective Tree (pohon tujuan) alat pemotong singkong [6] ;

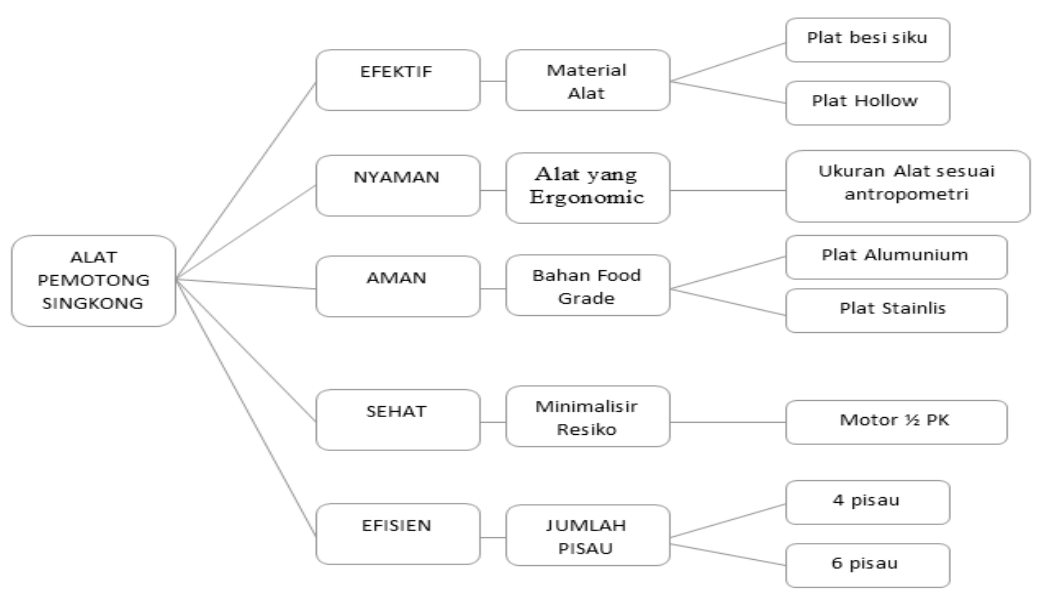

Gambar 2.Objective Tree 


\subsection{Establish Function}

Pada

tahapan establish function

(analisis

fungsi), akan

mempertimbangkan berbagai fungsi-fungsi dasar atau sub fungsi alat pemotong singkong dan tingkat masalahnya sebagai batasan dari kumpulan sub fungsi yang logis. Untuk menganalisis dan mempertimbangkan berbagai fungsi dan sub fungsi dapat dilihat pada gambar black box di bawah ini;

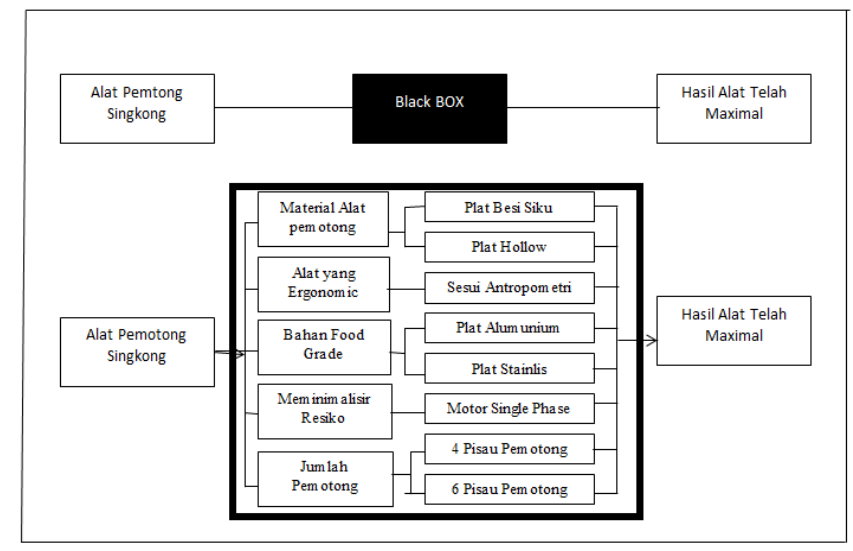

Gambar 3. Black Box Cross

\subsection{Setting Requirement}

Pada tahapan ini metode yang digunakan adalah The Performance Spesificasi Methods. Metode ini bertujuan membantu menemukan masalah perancang dan berbagai alternatif spesifikasi terhadap alat yang dapat meningkatkan peforma alat seperti berikut:

Tabel 1 Performance spesification perancangan alat pemotong singkong

\begin{tabular}{|c|c|c|}
\hline No & Tujuan & Kriteria \\
\hline 1 & Plat siku & Kuat dan ringan \\
\hline 1 & Plat hollow & Lebih kuat tetapi berat \\
\hline 2 & Sesuai ukuran Antropometri & Diukur rula atau reba \\
\hline 3 & Bahan aman untuk makanan (Aluminium) & $\begin{array}{l}\text { Tidak berkarat, tetapi kurang bagus untuk } \\
\text { makanan }\end{array}$ \\
\hline & Bahan aman untuk makanan (Stainlees) & Tidak berkarat, lebih aman untuk makanan \\
\hline 4 & Menggunakan motor & Menggunakan mesin singel phase \\
\hline & 4 pisau pemotong & Hasilnya lebih sedikit tetapi hasilnya bagus \\
\hline 5 & 6 pisau pemotong & $\begin{array}{l}\text { Hasilnya banyak tetapi hasilnya kurang } \\
\text { bagus }\end{array}$ \\
\hline
\end{tabular}

\subsection{Determining Characteristic (EFD)}

Tahapan ini menggunakan metode Ergonomic Function Deployment (EFD) merupakan metode yang terstruktur dalam pengembangan suatu produk dengan menetapkan semua keinginan dan kebutuhan konsumen. Dengan pemberian kuesioner kepada konsumen, dapat mengetahui tingkat kepuasan dan kepentingan 
konsumen. Berikut hasil penilaian tingkat kepuasan dan kepentingan konsumen [7]

Tabel 2 Penilaian Tingkat Kepentingan Konsumen

\begin{tabular}{|c|c|c|c|c|c|c|c|c|}
\hline \multirow{2}{*}{ No } & \multirow{2}{*}{ Pertanyaan } & \multicolumn{5}{|c|}{ Skala } & \multirow{2}{*}{ Total } & \multirow{2}{*}{$\begin{array}{l}\text { Nilai tingkat } \\
\text { kepentingan }\end{array}$} \\
\hline & & STP & TP & $\mathrm{CP}$ & $\mathrm{P}$ & SP & & \\
\hline 1 & Desain kontruksi yang kuat & 0 & 4 & 3 & 5 & 8 & 69 & 3.45 \\
\hline 2 & Waktu pemotongan singkong lebih cepat & 0 & 0 & 4 & 8 & 8 & 84 & 4.2 \\
\hline 3 & Alat pemotong singkong mudah digunakan & 0 & 3 & 7 & 8 & 2 & 77 & 3.85 \\
\hline 4 & Desain alat yang nyaman bagi pengguna & 0 & 1 & 7 & 8 & 4 & 75 & 3.75 \\
\hline 5 & Alat pemotong singkong yang aman digunakan & 0 & 5 & 4 & 2 & 9 & 75 & 3.75 \\
\hline 6 & Alat dapat mengurangi resiko kelelahan kerja & 0 & 3 & 5 & 5 & 7 & 76 & 3.8 \\
\hline 7 & $\begin{array}{l}\text { Material rangka pada alat pemotong singkong } \\
\text { yang kuat }\end{array}$ & 0 & 1 & 3 & 8 & 8 & 83 & 4.15 \\
\hline 8 & $\begin{array}{l}\text { Alat pemotong singkong mudah dalam } \\
\text { perawatannya }\end{array}$ & 0 & 1 & 7 & 8 & 4 & 75 & 3.75 \\
\hline & Total & & & & & & 629 & 31.45 \\
\hline
\end{tabular}

Tabel 3 Penilaian Tingkat Kepuasan

\begin{tabular}{|c|c|c|c|c|c|c|c|c|}
\hline \multirow{2}{*}{ No } & \multirow{2}{*}{ Pertanyaan } & \multicolumn{5}{|c|}{ Skala } & \multirow{2}{*}{ Total } & \multirow{2}{*}{$\begin{array}{l}\text { Nilai tingkat } \\
\text { kepuasan }\end{array}$} \\
\hline & & STP & TP & $\mathrm{CP}$ & $\mathrm{P}$ & SP & & \\
\hline 1 & Desain kontruksi yang kuat & 0 & 0 & 0 & 0 & 5 & 25 & 1.25 \\
\hline 2 & Waktu pemotongan singkong lebih cepat & 0 & 0 & 1 & 0 & 4 & 23 & 1.15 \\
\hline 3 & Alat pemotong singkong mudah digunakan & 0 & 0 & 0 & 4 & 1 & 21 & 1.05 \\
\hline 4 & Desain alat yang nyaman bagi pengguna & 0 & 0 & 0 & 2 & 3 & 23 & 1.15 \\
\hline 5 & Alat pemotong singkong yang aman digunakan & 0 & 1 & 0 & 0 & 5 & 27 & 1.35 \\
\hline 6 & Alat dapat mengurangi resiko kelelahan kerja & 0 & 0 & 0 & 2 & 3 & 23 & 1.15 \\
\hline 7 & $\begin{array}{l}\text { Material rangka pada alat pemotong singkong } \\
\text { yang kuat }\end{array}$ & 0 & 0 & 1 & 0 & 4 & 23 & 1.15 \\
\hline 8 & $\begin{array}{l}\text { Alat pemotong singkong mudah dalam } \\
\text { perawatannya }\end{array}$ & 0 & 0 & 0 & 2 & 3 & 23 & 1.15 \\
\hline & Total & & & & & & 188 & 9.4 \\
\hline
\end{tabular}

\subsection{Generating Alternatives}

Pada tahap ke lima mulai mencari solusi-solusi yang mungkin, metode yang digunakan adalah morphological chart method ini berguna memperluas pencarian solusi baru dengan membuat bagan yang memuat semua sub-solusi, setelah membuat bagan penulis akan mengkombinasi sub-solusi yang mungkin digunakan dalam perancangan alat pemotong singkong [8] . 
Tabel 4 Morphological Chart

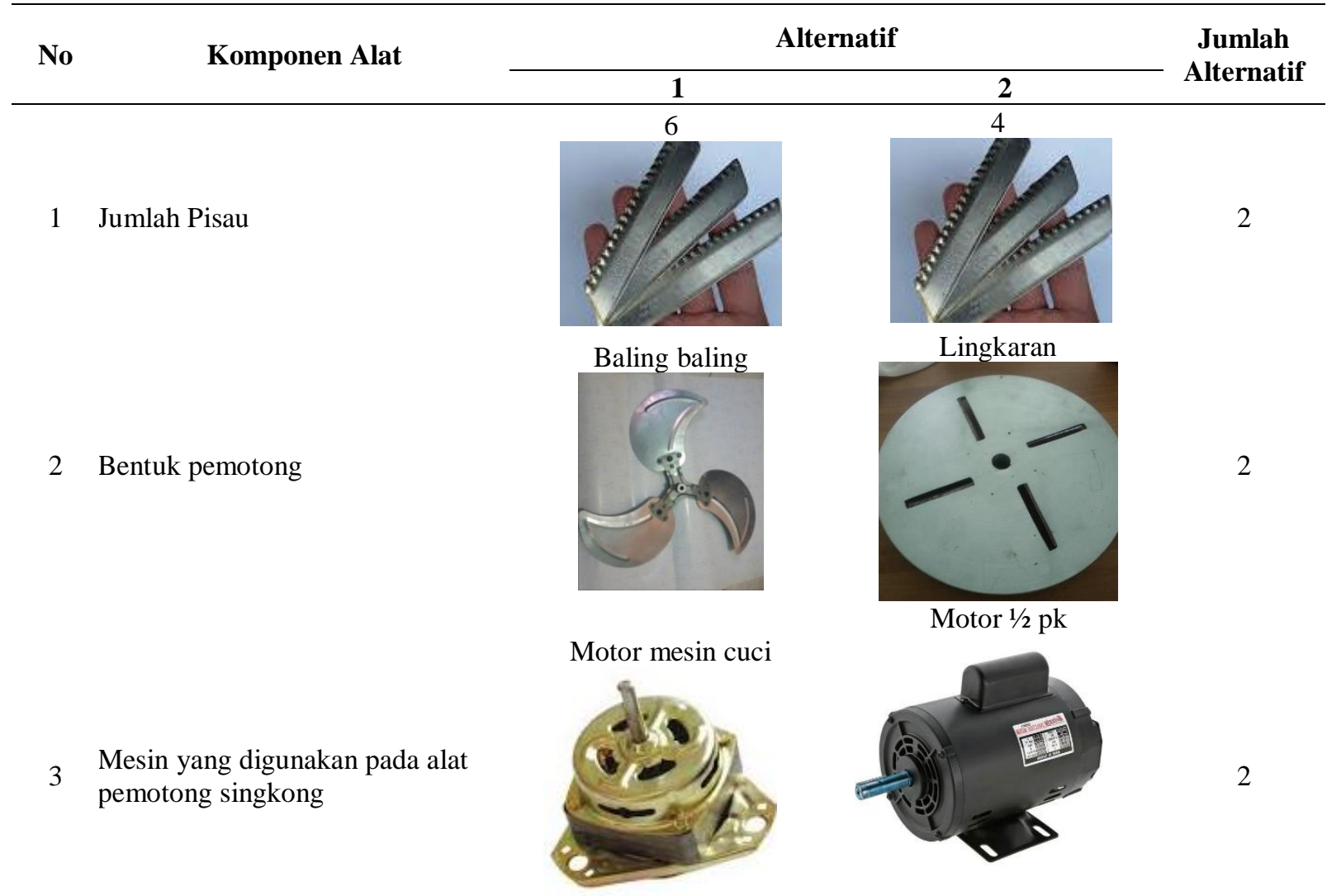

Plat alumunium

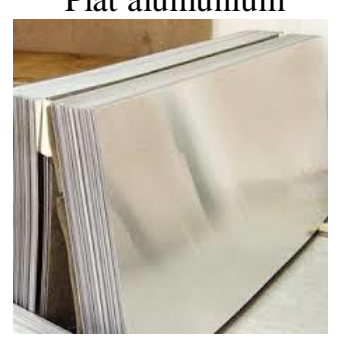

Besi hollow

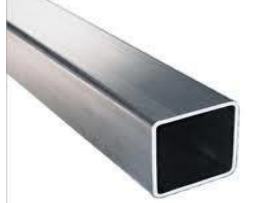

?lat stainlis

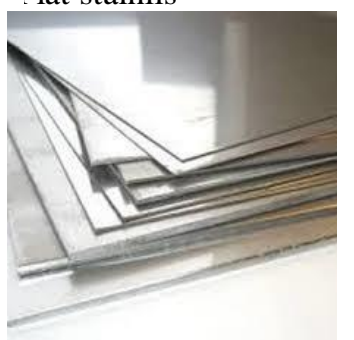

Besi siku

\subsection{Evaluating Alternative}

Tahapan selanjutnya mengevaluasi alternatif terbaik dari kombinasi sub-solusi dengan metode weight objectives (pembobotan obyektif), dimana dari alternatif kombinasi sub-sub solusi dari tahap ke lima metode rasional dipilih yang terbaik kemudian dan dihitung dan dibandingkan nilai kegunaan relatif perancangan alternatif pada tabel peformansi skala [9]..

a. Screening 
Screening merupakan tahapan pada evaluating alternative yang bertujuan untuk menyeleksi atau memilih alternatif terbaik dari perancangan alat pemotong singkong [10]

Tabel 5 Evaluating Alternatif

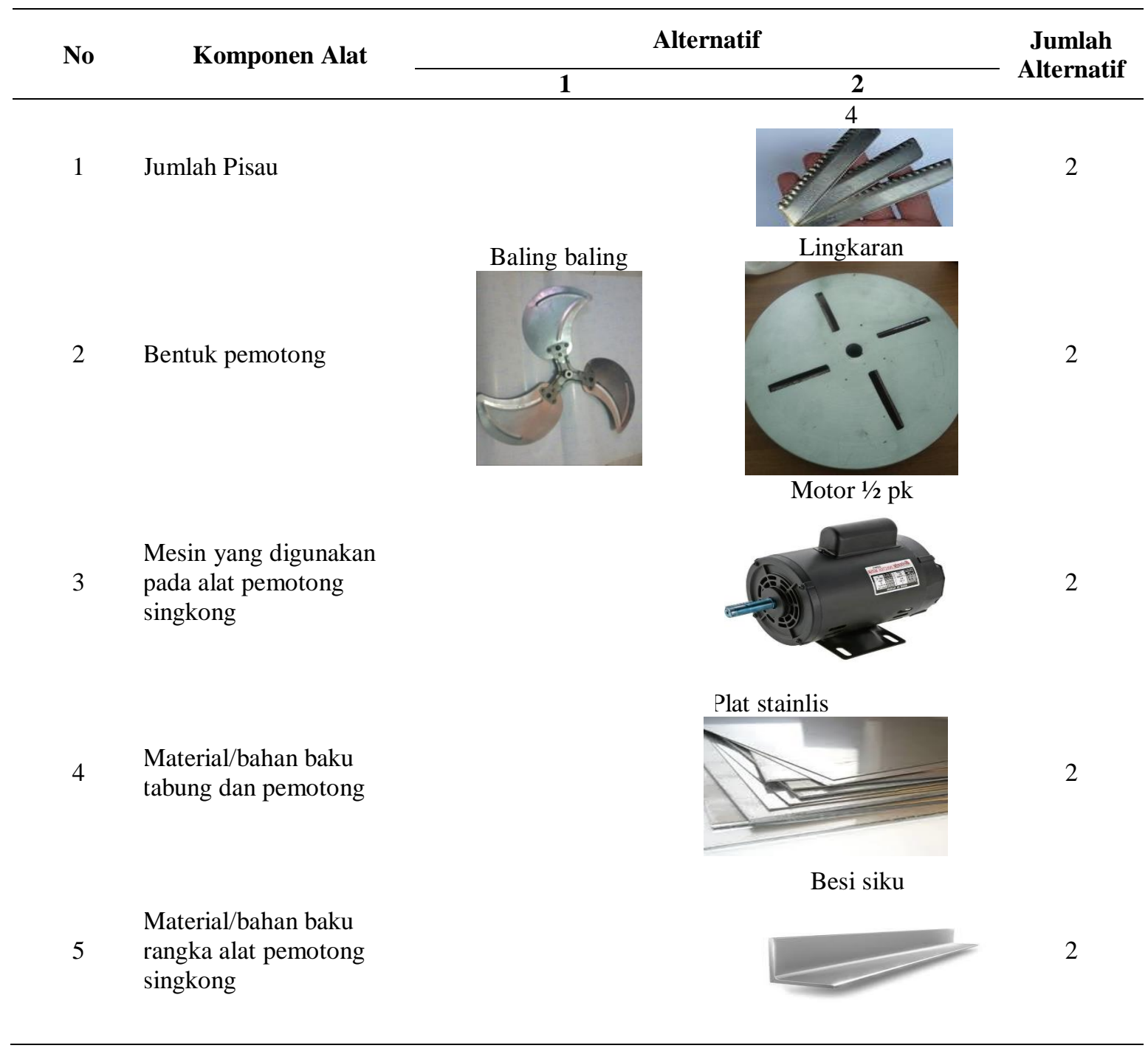

\section{b. Pembobotan}

Pada tahapan ini pembobotan kedua alternatif terbaik akan diberi nilai bobot dengan berdasarkan nilai rata-rata hasil preferentatif responden terhadap masing-masing kriteria pada kuesioner penelitian. Kriteria dengan nilai dengan nilai rata-rata terbesar akan mendapatkan rangking tertinggi serta memiliki bobot terbesar, dan kriteria dengan nilai rata-rata terkecil akan mendapatkan rangking terendah. 
Tabel 6 Pembobotan Alternatif

\begin{tabular}{llcccc}
\hline No & \multicolumn{1}{c}{ KRITERIA } & $\begin{array}{c}\text { RATA- } \\
\text { RATA }\end{array}$ & RANKING & NILAI & BOBOT \\
\hline 1 & Jumlah Pisau & 4.6 & 1 & 5 & 0.213 \\
2 & Bentuk pemotong & 4.4 & 5 & 1 & 0.204 \\
3 & Mesin yang digunakan pada alat pemotong singkong & 4.6 & 2 & 4 & 0.213 \\
4 & Material/bahan baku tabung dan pemotong & 3.8 & 3 & 3 & 0.176 \\
5 & Material/bahan baku rangka alat pemotong singkong & 4.2 & 4 & 2 & 0.194 \\
& $\quad$ JUMLAH & & & & 1 \\
\hline
\end{tabular}

c. Penilaian

Pada tahapan ini melakukan pemberian nilai kepada masing-masing kriteria dalam weight objectives chart untuk memilih salah satu alternatif, nilai yang diperoleh dari masing-masing kriteria merupakan hasil perkalian antar nilai dan bobot nilai. Penilaian dilakukan dengan menggunakan skala 5 titik dengan skala dimulai dari 0 sampai 4 .

Tabel 7 Hasil Pembobotan Alternatif Alat Pemotong Singkong

\begin{tabular}{|c|c|c|c|c|c|c|}
\hline \multirow{3}{*}{ No } & \multirow{3}{*}{ KRITERIA } & \multicolumn{4}{|c|}{ ALTERNATIF } & \\
\hline & & \multirow{2}{*}{ BOBOT } & 1 & \multicolumn{3}{|c|}{2} \\
\hline & & & Skor & $\begin{array}{l}\text { Nilai } \\
\text { Skor }\end{array}$ & Skor & $\begin{array}{l}\text { Nilai } \\
\text { Skor }\end{array}$ \\
\hline 1 & Jumlah Pisau & 0.213 & 4 & 0.85 & 4 & 0.85 \\
\hline 2 & Bentuk pemotong & 0.204 & 4 & 0.81 & 4 & 0.81 \\
\hline 3 & $\begin{array}{l}\text { Mesin yang digunakan pada alat } \\
\text { pemotong singkong }\end{array}$ & 0.213 & 3 & 0.64 & 4 & 0.85 \\
\hline 4 & $\begin{array}{l}\text { Material/bahan baku tabung dan } \\
\text { pemotong }\end{array}$ & 0.176 & 3 & 0.53 & 4 & 0.70 \\
\hline 5 & $\begin{array}{l}\text { Material/bahan baku rangka alat } \\
\text { pemotong singkong }\end{array}$ & 0.194 & 3 & 0.58 & 4 & 0.78 \\
\hline & Total & & 2.83 & & 3.22 & \\
\hline & Ranking & & 2 & & 1 & \\
\hline & Lanjutkan & & $x$ & & $\sqrt{ }$ & \\
\hline
\end{tabular}

\subsection{Product Improvement}

Pada tahapan terakhir metode rasional dapat dilakukan penyempurnaan produk atau alat hasil rancangan, penyempunaan dilakukan setelah alat dibuat atau digunakan oleh pengguna/konsumen dilihat dari segi kenyamanan dan estetika produk atau alat. 


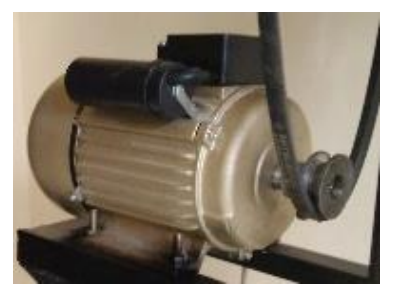

Gambar 8. Motor listrik

Motor listrik sebagai pengganti tenaga manusia, dengan motor yang memiliki tenaga $1 / 2$ pk mampu memutar pisau pemotong singkong.

\subsection{Rancangan alat}

Rancangan alat dibuat menggunakan aplikasi Solid Work dengan ukuran berdasarkan data antropometri TSB (tinggi siku berdiri) dan JT (jangkauan tangan).

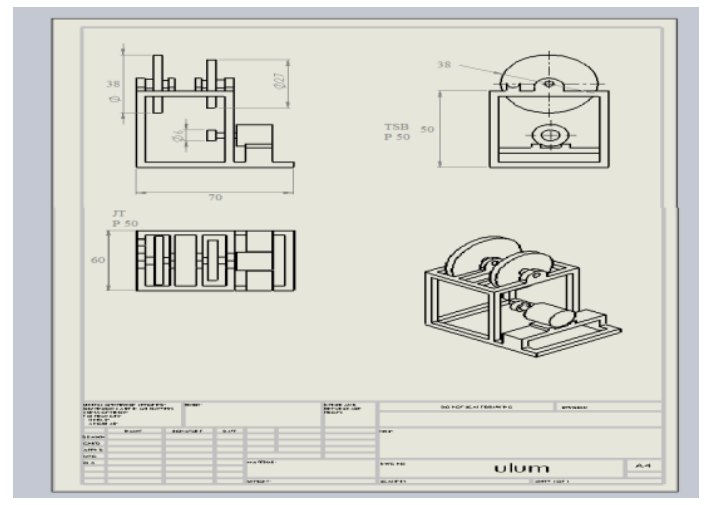

Gambar 9. Gambar teknik alat pemotong singkong

\subsection{Implementasi Produk dan Hasil}

Implementasi alat pada UKM Mubarok bertujuan untuk mengetahui kinerja dari alat dan berapa lama waktu yang dibutuhkan dalam pemotongan singkong.

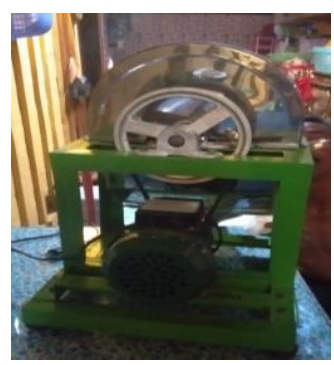

Gambar 10 Implementasi alat ke UKM Mubarok

Setelah proses pemotongan singkong menggunakan alat pemotong singkong yang baru didapatkan hasil waktu proses pemotongan singkong sebagai berikut: 
Tabel 5 Perbedaan alat lama dan alat baru

\begin{tabular}{lll}
\hline \multicolumn{1}{c}{ Parameter } & \multicolumn{1}{c}{ Alat lama } & \multicolumn{1}{c}{ Alat baru } \\
\hline Jumlah produk & 20 kg/jam & $60 \mathrm{~kg} / \mathrm{jam}$ \\
Waktu pemotongan & $\pm 20 \mathrm{menit} / 3 \mathrm{~kg}$ & $\pm 3 \mathrm{menit} / 3 \mathrm{~kg}$ \\
Kualitas produk & Kurang presisi & Presisi \\
\hline
\end{tabular}

\section{Kesimpulan}

Berdasarkan penelitian perancangan alat pemotong singkong dengan menggunakan metode rasional yang telah dilakukan menghasilkan:

a. Terjadi penurunan waktu pemotongan dan peningkatan kualitas produk. Pemotongan menggunakan alat lama didapatkan $3 \mathrm{~kg}$ singkong per 20 menit, sedangkan pemotongan menggunakan alat baru didapatkan $3 \mathrm{~kg}$ singkong per 3 menit. Dengan menggunakan alat baru memiliki tingkat kepresisian tertinggi 95\% dengan tingkat ketebalan produk $0.3 \mathrm{~cm}$.

b. Meningkatnya efisiensi waktu pemotongan dan jumlah produk.

Penurunan waktu pemotongan singkong meningkatkan efisiensi sebesar $85 \%$, produk yang dihasilkan setiap jam meningkat, menggunakan alat lama hanya menghasilkan $20 \mathrm{~kg} / \mathrm{jam}$, sedangkan menggunakan alat baru menjadi 60kg/jam. Dari peningkatan jumlah produk meningkatkan efisiensi sebesar $83 \%$.

\section{Saran}

Penelitian selanjutnya perlu mengkaji tentang kualitas hasil potongan sehingga akan menguangi produk singkong hasil potongan yang reject.

\section{Referensi}

[1] Anwar, Khoirul, M. Perancangan Alat Pemotong Kue Yangko dengan Teknik Sling Cutting Guna Meningkatkan Produktivitas Menggunakan Metode Rasional. Universitas Dian Nuswantoro. Semarang. 2017.

[2] Cohen, Lou. Quality Function Deployment, How to Make QFD Work for tou. 1995. Addison-Wesley Publishing Company: New York.

[3] Cross, N. Engineering Design Methods Strategies for Product Design. Edisi 2. 1994. Jhon Wiley and Sons Ltd. United Kingdom.

[4] Eko, Putro. Alat pemotong singkong dengan mekanisme pedal kaki dengan pendekatan Antopometry: Surabaya. 2009.

[5] Harsiyanto Sri. Ashari. Desain Mesin Pemotong kue Bolu dengan Teknologi VHDL berbasis CPLDM XS 95-108 Board. 2011.

[6] Hendrawan Y, dkk. Rancang Bangun dan Uji Performansi Alat Pemotong Kentang Bentuk Frech Fries. Universitas Brawijaya: Malang. 2015.

[7] Ulrich, T Kalt Epingger, D Steven. 2001. Perancangan dan Pengembangan Produk. Jakarta; Salemba. Teknika.

[8] Sularso; Suga, Kiyokatsu. Dasar Perencanaan DanPemilihan Elemen Mesin, Pradnya Paramita : Jakarta.2002 Pawirodrikomo,Widodo, Analisis Tegangan Bahan.Pustaka Pelajar: Jakarta.2014

[9] Mott,Robert L. Elemen- Elemen Mesin dalam Perancangan Mekanis (Perancangan Elemen Mesin Terpadu) 1.Yogyakarta: Penerbit Andi.2009

[10] Darmawan.H, Pengantar Perancangan Teknik, Direktorat Jendra Pendidikan Tinggi;Jakarta.1992. 